\title{
ELECTRO-ENCEPHALOGRAPHY IN A CASE OF ISLET CELL ADENOMA
}

\author{
BY \\ JOHN LAIDLAW* and S. M. RAB \\ From Hammersmith Hospital and Postgraduate Medical School of London
}

Organic hyperinsulinism has been the subject of recent full reviews (Breidahl, Priestley, and Rynearson, 1956; Skillern and Rynearson, 1953; Duncan, 1952; Howard, Moss, and Rhoads, 1950; Crain and Thorn, 1949), but this case is discussed for the following particular reasons:-

(1) In order to emphasize the importance of considering hyperinsulinism as a differential diagnosis of the epilepsies and the psychoneuroses.

(2) Because it has been often stated (Breidahl et al. 1956; Black, Corbett, Hosford, and Turner, 1954; Crain and Thorn, 1949) that the electro-encephalogram (E.E.G.) is of little value in the diagnosis of this condition and this case shows that, properly applied, it may make a valuable contribution.

(3) Because the case presents certain rather unusual features about the form of the attacks and also about the E.E.G. findings. It is possible that there may be a correlation of some theoretical interest between the two.

\section{Case Report}

A married woman, aged 24, was admitted on February 20,1957 , four months after the birth of her first baby.

Since the age of 17 she had had difficulty in waking up in the morning. She would lie with her eyes open but would appear dazed and confused: although in touch with her surroundings she was slow to answer questions and showed little spontaneous activity, There was no sweating or tremulousness, she did not complain of hunger or other symptoms, and apart from her "sleepiness" she appeared normal and healthy. These attacks were self-limiting but she would be "weak on her legs" until she had breakfasted. They occurred at variable intervals on an average once or twice a month and with little change in severity or frequency over a period of about six years. Between attacks she was very shorttempered and showed mild neurotic symptoms. She was considered to be suffering from hysteria and no special treatment was given.

During her pregnancy she improved and towards the end was free of attacks. Shortly after the birth of her baby the attacks returned, but although they still occurred

\footnotetext{
*In receipt of a personal grant from the Medical Research Council.
}

in the early morning they had changed their character and increased in severity. There were about 12 attacks in which she became drowsy, might complain of tingling in the fingers, started to make facial movements including smacking of the lips, and very shortly had a generalized convulsion from which she recovered after a short period of unconsciousness.

At 9 a.m. on January 1, 1957, she was attending to her baby before taking her own breakfast. Suddenly she called to her husband that she was going to have one of her attacks and told him to take the baby. Almost immediately she appeared to lose her reason, became maniacal, threw herself about the room, and tried to attack the child whom her husband was now holding. This behaviour lasted several minutes and was only terminated by a typical major convulsion. When she had not recovered consciousness after one and a half hours she was sent to another hospital with the diagnosis of epilepsy.

On admission she was found to be in coma with bilateral extensor plantar responses but no other relevant physical signs. Twenty-four hours after admission a sample of blood was reported as showing $12 \mathrm{mg}$. \% glucose. Despite immediate treatment with large quantities of intravenous glucose she remained stuporose for several days. For two weeks after regaining consciousness she was confused, unable to answer simple questions, and disorientated with a markedly impaired memory and slurred speech. After a further two weeks she had returned to normal and shortly afterwards was transferred to Hammersmith Hospital for confirmation of suspected organic hyperinsulinism.

On admission on February 20, 1957, she presented as a normal, healthy, slightly overweight young woman of average intelligence. She was anxious, a little facetious, and showed some emotional lability. There were no significant physical signs. Four random early-morning blood sugar estimations gave values of $27,49,62$, and $51 \mathrm{mg}$. per $100 \mathrm{ml}$. Serum electrolytes, liver function tests, urinary ketosteroids, a water load test, radiographs of the chest, skull, and abdomen, and a barium meal were normal. A routine E.E.G. showed (1) short bursts of high-amplitude, regular bilaterally synchronous 3 cycles per second (c.p.s.) waves maximal anteriorly, provoked by over-breathing, and (2) an abnormality localized to the right postero-lateral area as shown by phase reversal of occasional, moderate-amplitude slow-wave complexes. 
The first finding had no significance unless related to blood sugar levels, the second suggested minimal cerebral damage.

At this stage the diagnosis of hypoglycaemia due to organic hyperinsulinism was considered very probable. For confirmation sufficient to recommend laparotomy it was desirable to reproduce the patient's symptoms by starvation and to alleviate them by giving sugar. However, this patient did not have the usual premonitory symptoms associated with sympatho-adrenal activity; she passed suddenly from a state of apparent complete normality to one of altered consciousness, psychotic behaviour, and convulsions.

In order to avoid reproducing symptoms of this severity, serial E.E.G.s were recorded during the latter part of a 22-hour fast (Table I, Fig. 1). A significant E.E.G. abnormality was reproduced by fasting; at the same time the blood sugar was found to be $38 \mathrm{mg}$. per $100 \mathrm{ml}$., and the effective plasma insulin activity by Vallence-Owen and Hurlock's rat diaphragm method (1954) was shown to be 300 micro-units/ml. One hundred grams of glucose were given by mouth and the significant E.E.G. abnormality was completely corrected. At no time during this test did the patient complain of any symptoms other than hunger and she showed no signs of hypoglycaemia. It was felt that Whipple's criteria for exploratory laparotomy (Whipple, 1944) had been satisfied without unpleasantness for, or risk to, the patient.

On March 21 Professor Aird removed a benign adenoma $(25 \times 20 \times 14 \mathrm{~mm}$. $)$ from the head of the pancreas.
TABLE I

PRE-OPERATIVE E.E.G. SERIES SHOWING BLOOD SUGAR LEVELS, FIRST OCCURRENCE OF, AND PERCENTAGE RECORDING TIME OCCUPIED BY LARGE SLOW WAVES, NUMBER OF LOCALIZED ABNORMAL COMPLEXES, AND PLASMA INSULIN ACTIVITY

\begin{tabular}{|c|c|c|c|c|c|c|}
\hline Time & $\left.\mid \begin{array}{c}\text { Blood } \\
\text { Sugar } \\
\text { (mg.\%) }\end{array}\right)$ & $\begin{array}{l}\text { E.E.G. } \\
\text { No. }\end{array}$ & $\begin{array}{l}\% \text { Time } \\
\text { Slow } \\
\text { Activity }\end{array}$ & $\begin{array}{c}\text { Time of } \\
\text { Appearance } \\
\text { of First } \\
\text { Slow } \\
\text { Activity }\end{array}$ & \begin{tabular}{|c|} 
No. of \\
Localized \\
Abnormal \\
Complexes
\end{tabular} & $\begin{array}{l}\text { Plasma } \\
\text { Insulin } \\
\text { Activity }\end{array}$ \\
\hline 10.15 a.m. & - & I : 1 & $1 \cdot 2$ & $\begin{array}{c}130 \mathrm{sec} . \\
0-\mathrm{B}\end{array}$ & & - \\
\hline 11.45 a.m. & - & I : 2 & $2 \cdot 9$ & $\begin{array}{r}85 \mathrm{sec} . \\
0-\mathrm{B}\end{array}$ & 7 & 一 \\
\hline $\begin{array}{l}12.45 \text { p.m. } \\
1.30 \text { p.m. }\end{array}$ & 51 & $I \overline{1}: 3$ & $\overline{2 \cdot 4}$ & $\begin{array}{c}100 \mathrm{sec} . \\
0-\mathrm{B}\end{array}$ & $\overline{8}$ & = \\
\hline $\begin{array}{l}2.45 \text { p.m. } \\
3.30 \text { p.m. }\end{array}$ & $\begin{array}{l}43 \\
38\end{array}$ & $\bar{I}: 4$ & $\overline{9 \cdot 0}$ & & $\overline{21}$ & $\begin{array}{c}\overline{300} \\
\text { micro } \\
\text { units/ } \\
\text { ml. }\end{array}$ \\
\hline 4.00 p.m. & \multicolumn{3}{|c|}{$100 \mathrm{~g}$. glucose by mouth } & & & \\
\hline $\begin{array}{l}4.30 \text { p.m. } \\
5.00 \text { p.m. }\end{array}$ & $\begin{array}{r}114 \\
57 \\
\end{array}$ & $\begin{array}{l}1: 5 \\
1: 6 \\
\end{array}$ & $\begin{array}{l}\mathbf{0} \\
\mathbf{0} \\
\end{array}$ & $\begin{array}{l}\text { Absent } \\
\text { Absent }\end{array}$ & $\begin{array}{l}0 \\
1 \\
\end{array}$ & 二 \\
\hline
\end{tabular}

The fasting serial E.E.G. test was repeated (Table II) on April 9. Blood sugar levels were essentially normal, the fasting plasma insulin activity was $\mathbf{3 0}$ micro-units $/ \mathrm{ml}$., and no high-voltage slow waves were recorded electrically.

The patient was discharged from hospital on May 18. She had had no hypoglycaemic attacks since her operation. As on admission, there were no significant physical signs. Her mental state was within normal limits; it was not possible to say whether a slight facetiousness was a

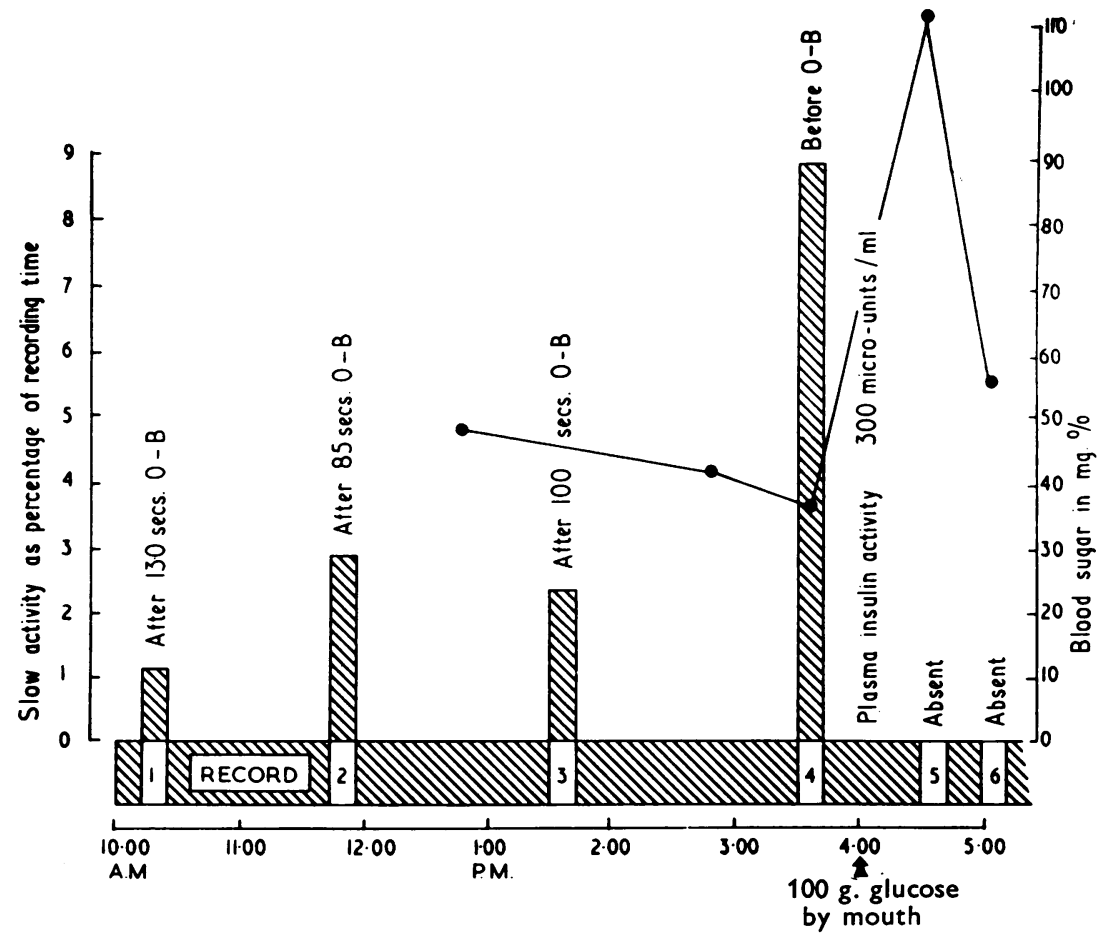

FIG. 1.-Pre-operative fastingE.E.G. test. The columns represent the percentage of recording time during which large slow waves occur: the time of the first appearance of these waves is written at the top of each column. Records I : 5 and I : 6, after glucose has been given, show no such abnormality. The results of five estimations of blood sugar are also shown. 
part of her premorbid personality, but she appeared less nervous and emotionally labile.

\section{Details of E.E.G. Findings}

Series I. -The patient was starved from $6 \mathrm{p} . \mathrm{m}$. on February 29, 1957. The next day six E.E.G.s were recorded between 10.15 a.m. and 5 p.m. The temporal electrode position was used for each recording which lasted 10 minutes: five minutes before and two minutes after three minutes of over-breathing. One hundred grams of glucose were given at 4 p.m. between records 4 and 5 (Table I, Fig. 1).

In each record there was a well formed although scanty alpha rhythm with frequencies at 10 and 11 c.p.s. There was no evidence of slowing of the dominant frequency or of generalized theta (4-7 c.p.s.) activity.

The localized abnormality seen in the routine record was again present and showed some aggravation by hypoglycaemia (Table I).

The main feature of this series was high-voltage slow activity. There were bursts of regular bilaterally synchronous waves at $2 \frac{1}{2}$ and 3 c.p.s. maximal anteriorly. Hypocapnoea and hypoglycaemia act synergically in evoking such activity (Brazier, Finesinger, and Schwab, 1944) and in the first three records these waves only occurred during over-breathing. The percentage time of these slow waves and the time of over-breathing necessary to induce them are shown in Fig. 1 and Table I. It will be seen that in record 4, just before glucose was given, not only is there a greatly increased incidence of these waves but they occur during the resting record without the provocation of over-breathing. This finding in itself, but particularly in comparison with earlier records in the series, was considered to be significant and to suggest the probability that an alteration in consciousness would soon be manifest clinically. Throughout this crucial record the patient felt and looked perfectly normal. Fig. 2, taken from record 4, showis a burst of high-voltage slow waves appearing against an essentially normal background.

No high-voltage slow waves were recorded after glucose had been given (records 5 and 6 ), even during over-breathing.

Series II.-The series of six records was repeated on April 9 under similar conditions. There had been a significant alteration in the alpha rhythm which was about twice the previous amplitude, plentiful and with frequencies reduced to 9 and 10 c.p.s.

The localized abnormality was not significantly altered and once again was more prominent during the fasting records.
FIG. 2.-A specimen of the preoperative record I : 4 showing large regular bilaterally synchronous slow waves appearing suddenly from an essentially normal background.
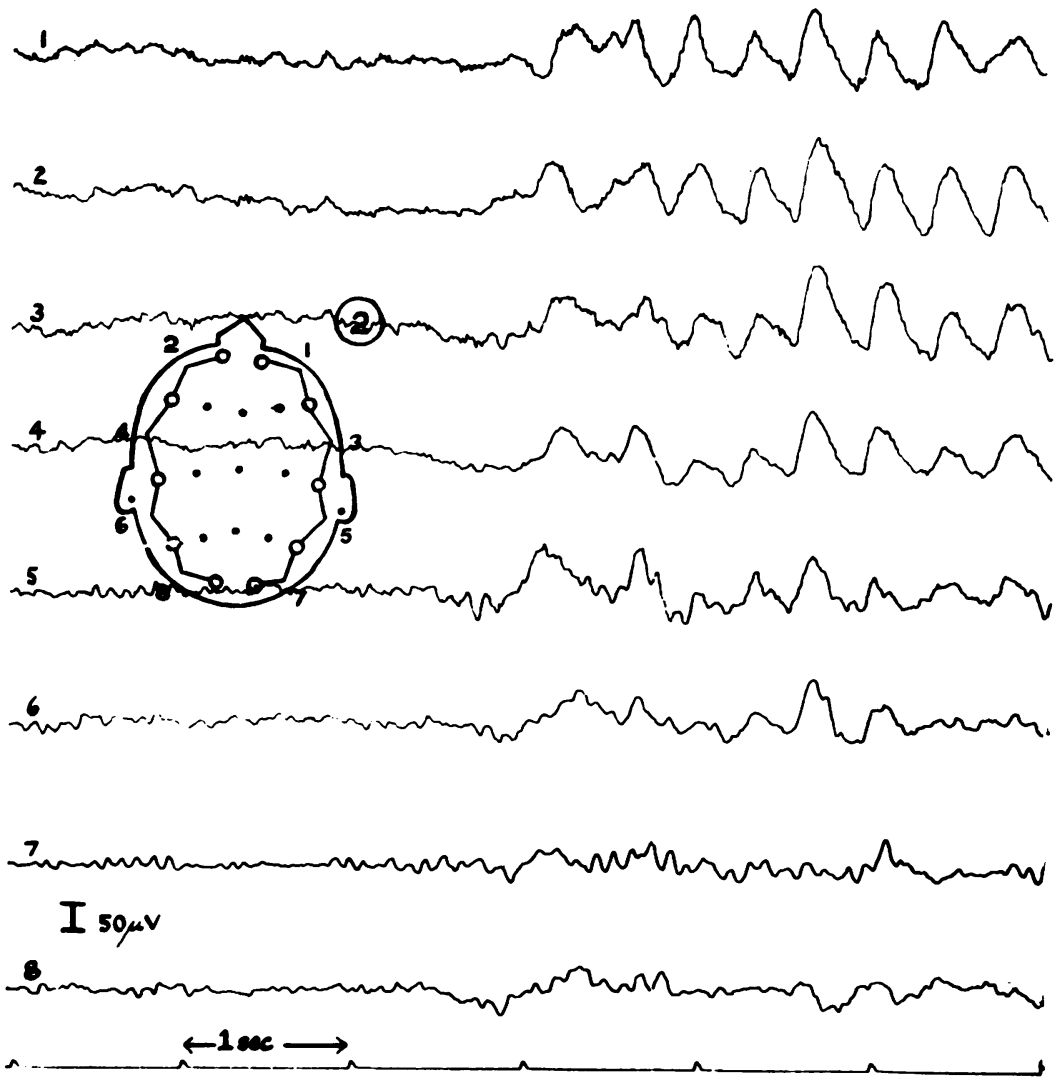
TABLE II

POST-OPERATIVE E.E.G. SERIES SHOWING BLOOD SUGAR LEVELS, NUMBER OF LOCALIZED ABNORMAL COMPLEXES, AND PLASMA INSULIN ACTIVITY

\begin{tabular}{|c|c|c|c|c|}
\hline Time & $\underset{(\mathrm{mg} . \%)}{\text { Blood Sugar }}$ & $\begin{array}{l}\text { E.E.G. } \\
\text { No. }\end{array}$ & $\begin{array}{c}\text { No. of Localized } \\
\text { Abnormal } \\
\text { Complexes }\end{array}$ & $\begin{array}{l}\text { Plasma } \\
\text { Insulin } \\
\text { Activity }\end{array}$ \\
\hline $\begin{array}{l}10.00 \text { a.m. } \\
11.20 \text { a.m. } \\
1.05 \text { p.m. } \\
2.30 \text { p.m. }\end{array}$ & $\begin{array}{l}72 \\
87 \\
63 \\
85\end{array}$ & $\begin{array}{l}\text { II }: 1 \\
\text { II }: 2 \\
\text { II }: 3 \\
\text { II }: 4\end{array}$ & $\begin{array}{r}19 \\
26 \\
7 \\
5\end{array}$ & $\begin{array}{c}\bar{z} \\
\bar{z} \text { micro } \\
\text { units/ml. }\end{array}$ \\
\hline 4.00 p.m. & \multicolumn{2}{|c|}{100 g. glucose by mouth } & & \\
\hline $\begin{array}{l}4.05 \text { p.m. } \\
4.30 \text { p.m. } \\
5.25 \text { p.m. } \\
6.05 \text { p.m. }\end{array}$ & $\begin{array}{l}2 \overline{17} \\
200 \\
246\end{array}$ & $\begin{array}{l}\text { II }: 5 \\
\text { II }: 6 \\
=\end{array}$ & $\begin{array}{l}1 \\
-\end{array}$ & $\begin{array}{l}\bar{z} \\
\bar{z}\end{array}$ \\
\hline
\end{tabular}

No high-voltage slow waves were recorded in this series.

Blood sugar levels and the incidence of the localized abnormal complexes are given in Table II.

\section{Comment}

The wide variation between the records of different individuals and the vagueness of the abnormalities which occur probably explain why the E.E.G. is considered of comparatively little value in the diagnosis of "metabolic" conditions. These objections become less valid if serial records are made and if variations within the series are correlated with clinical changes as a result of test situations or treatment.

The electrical changes in hypoglycaemia have also been criticized because of the poor correlation between the severity of E.E.G. abnormalities and the blood sugar level (Bonnet and Malpertuy, 1955; Black et al., 1954; Solis and Vara Lopéz, 1954; Hoefer, Guttman, and Sands, 1946). However, Bonnet and Malpertuy (1955), Gibbs and Murray (1954), Wyke (1952), and many other workers have also drawn attention to the lack of parallelism between the clinical state and the levels of blood sugar. The clinical state depends primarily on the level of cerebral metabolism and only secondarily on the amount of sugar which is reaching the brain to maintain this metabolism. Himwich, Bowman, Daly, Fazekas, Wortis, and Goldfarb (1940) showed that in therapeutic insulin coma the blood sugar fell rapidly and remained at a fairly steady low level, whereas there was a much more gradual fall in the rate of cerebral metabolism as shown by the reduction in arteriovenous oxygen difference, the reduction of the metabolism to very low levels being a function not only of the level of the blood sugar but of the time during which it had been low. The same authors (Himwich, Frostig, Fazekas, and Hadidian, 1939), again working with carefully controlled comas, found that there was a better corre- lation between brain oxygen uptake, E.E.G. abnormalities, and symptoms than there was between any of these variables and the level of the blood sugar. It would be expected that the blood sugar would provide even less reliable correlations in cases of organic hyperinsulinism when the secretion of insulin is known to be very variable.

It is felt that serial E.E.G.s can, in suitable cases, give some direct and objective measure not of the level of the blood sugar, which can be obtained more simply, but of the much more important effect of hypoglycaemia on cerebral function. It is interesting that Whipple (1944) suggested that E.E.G.s run in parallel with glucose tolerance tests might prove valuable.

The minimal localized abnormality which has been a feature of all the records may possibly represent minimal residual cerebral damage, probably resulting from the prolonged "irreversible" coma in January. It is well known (Bickerstaff, Dodge, Gourevitch, and Hearn, 1955; Gibbs, Gibbs, and Lennox, 1939; Malamud and Grosh, 1938) but important to emphasize that a generalized metabolic insult may cause a temporary or permanent localized clinical or electrical cerebral abnormality.

The increase of this abnormality in the fasting records of our patient, both before and after operation, confirms the finding of Ross and Loeser (1951) that hypoglycaemia can aggravate E.E.G. abnormalities other than the classical wave-andspike complexes as stated by Gibbs et al. (1939).

Although high-voltage slow waves are considered as typical of severe hypoglycaemia, as of other severe metabolic disorders, it is usual for the first electrical changes to consist of a slowing of the dominant alpha rhythm and the gradual appearance of slower waves within the theta (4-7 c.p.s.) range; the large slow waves when they cccur rise against a background which is already quite definitely abnormal (Regan, Browne-Mayers, and Evarts, 1955; Bonnet and Malpertuy, 1955; Heppenstall and Greville, 1950).

In our case the slow waves, which were the main feature of the pre-operative records, arose from an essentially normal background. Since these large slow waves are usually associated with disorders of consciousness, it is interesting to speculate whether there is any connexion between the sudden appearance of slow waves against a normal background and the appearance of sudden alteration of consciousness without the usual premonitory symptoms.

Far from there being a slowing of the alpha rhythm due to hypoglycaemia, there was a slight but definite and significant slowing of the alpha rhythm after operation when the patient's blood 
sugar levels were normal. It is possible that this slowing, associated with the increase in the amount and amplitude of the alpha rhythm, was due to the reduction in nervousness which was apparent clinically after operation. It is interesting that one of the first cases of organic hyperinsulinism reported in this country by Fraser, Maclay, and Mann (1938) was of a young woman who suffered from neurasthenic symptoms, which persisted between her attacks and were relieved by operation.

\section{Summary}

The case is described of a young woman who suffered from organic hyperinsulinism due to an islet cell adenoma of the pancreas. For six years she masqueraded as an hysteric and later as an epileptic. The diagnosis was suspected after a severe attack and was confirmed by a fasting test in association with serial electro-encephalograms and estimation of plasma insulin activity.

The appearance of non-specific E.E.G. abnormalities suggesting a disorder of cerebral metabolism anticipated any clinical manifestation, and the diagnostic value of such non-specific changes in controlled test situations is stressed.

Certain interesting clinical and electrical findings are reported.

We wish to thank Dr. Wolstencroft, Dr. Goodwin, and Professor Aird for permission to report this case which has been under their care, and Dr. Vallance-Owen for his estimation of plasma insulin activity.

\section{REFERENCES}

Bickerstaff, E. R., Dodge, O. G., Gourevitch, A., and Hearn, G. W. (1955). Brit, med. J., 2, 997.

Black, K. O. Corbett, R. S., Hosford, J. P., and Aldren Turner, J. W. (1954). Ibid., 1, 55.

Bonnet, H., and Malpertuy, G. (1955). Electroenceph. clin, Neurophysiol., 7, 151 .

Brazier, M. A. B., Finesinger, J. E., and Schwab, R. S. (1944). J. clin. Invest., 23, 313, 319

Breidahl, H. D., Priestley, J. T., and Rynearson, E. H. (1956). J. Amer. med. Ass., 160, 198.

Crain, E. L., and Thorn, G. W. (1949). Medicine (Baltimore), $28,427$.

Duncan, G. G. (1952). Diseases of Metabolism. 3rd ed. Saunders, Philadelphia.

Fraser, R., Maclay, W. S., and Mann, S. A. (1938). Quart. J. Med., 7,115 .

Gibbs, F. A. and Murray, E. L. (1954). Electroenceph. clin. Neurophysiol., 6, 674 .

Gibbs, E. L., and Lennox, W. G. (1939). Arch. Neurol. Psychiat. (Chicago), 41, 1111.

Heppenstall, M. E., and Greville, G. D. (1950). In Electroencephalography. Ed. Hill, J. D. N., and Parr, G. Macdonald, London.

Himwich, H. E., Bowman, K. M., Daly, C., Fazekas, J. F., Wortis, J., and Goldfarb, W. (1940). Proc. Soc. exp. Biol. (N.Y.), 45, 468 Frostig. J. P. Fazekas, J. F., and Hadidian, Z. (1939). Amer. J. Psychiat., 96, 371 .

Hoefer, P. F. A., Guttman, S. A., and Sands, I. J. (1946). Ibid.,

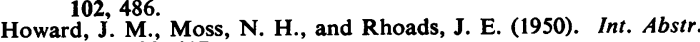
Surg., 90, 417.

Malamud, N., and Grosh, L. C. (1938). Arch. intern. Med., 61, 579 Regan, P. F., Browne-Mayers, A. N., and Evarts, E. N. (1955)

Ross, I. S., and Loeser, L. H. (1951). Ibid., 3, 141.

Skillern, P. G., and Rynearson, E. H. (1953). J. clin. Endocr., 13, 587. (1) Solis, J., and Vara Lopéz, R. (1954). Electroceph. clin. Neurophysiol. 6,529 .

Vallance-Owen, J., and Hurlock, B. (1954). Lancet, 1, 68.

Whipple, A. (1944). Surgery, 16, 289.

Wyke, B. D. (1952). Electroceph. clin. Neurophysiol., 4, 339. 